\title{
MITOS DAN BUDAYA
}

\author{
Mia Angeline \\ Marketing Communication Department, Faculty of Economics and Communication, BINUS University \\ Jln. K.H. Syahdan No.9, Palmerah, Jakarta Barat 11480 \\ f.angeline@gmail.com
}

\begin{abstract}
This article describes the role of myth and some universal themes of myth, such as the creation of the world, a huge flood, death, and the end of the world. Almost all the world's myths concern this universal themes, as seen from the similarity of some of the myths followed by many cultures in the world. These myths have primary functions to human's behavior and attitude because people keep telling almost the same myths to their predecessors. The goals for this research are (1) knowing the functions of myths with famous themes from various culture and (2) knowing the background and relationship between myths and modern culture. The result describes the relationship between the cultural myths, where the core of the story is the truth of humanity. In addition, myth acts as a template to organize their daily activities as well as human activity, but it also serves to introduce human to a greater power in the universe. The values in each story will be interpreted as rules and customs that must be met, and this has resulted in the emergence of a culture passed down from generation to generation.
\end{abstract}

Keywords: myth, culture, the creation of the world, death, the end of the world

\begin{abstract}
ABSTRAK
Artikel menjelaskan peran mitos dan beberapa tema universal dari mitos, yaitu mengenai penciptaan dunia, bencana banjir besar, kematian, dan mitos akhir dunia. Hampir seluruh mitos di dunia menyangkut tema universal tersebut yang terlihat dari kemiripan beberapa mitos yang dipercaya oleh berbagai kebudayaan di dunia. Mitos yang diturunkan memiliki fungsi dan hubungan dengan kehidupan modern karena tanpa sadar manusia terus menurunkan mitos secara turun temurun. Penelitian bertujuan untuk (1) mengetahui fungsi dari mitos-mitos dengan tema paling terkenal dari kebudayaan-kebudayaan di dunia dan (2) mengetahui latar belakang dan hubungan antara mitos dengan budaya masyarakat modern. Hasil penelitian menjelaskan hubungan antara mitos dengan budaya, dengan inti dari cerita di dalam mitos adalah kebenaran mengenai manusia. Mitos bertindak sebagai template untuk mengatur kegiatan sehari-hari serta aktivitas manusia. Selain itu mitos juga berperan memperkenalkan manusia kepada kekuatan yang lebih besar di alam semesta. Nilainilai yang dibawa dalam setiap cerita akan diartikan sebagai aturan dan kebiasaan yang harus dipenuhi, dan hal ini berujung pada munculnya budaya yang diwariskan turun temurun.
\end{abstract}

Kata kunci: budaya, mitos penciptaan, mitos banjir besar, mitos kematian, mitos akhir dunia 


\section{PENDAHULUAN}

Mitos (myth) adalah cerita rakyat yang tokohnya para dewa atau makhluk setengah dewa yang terjadi di dunia lain atau masa lampau dan dianggap benar-benar terjadi oleh penganut cerita tersebut. Mitos berasal dari bahasa Yunani muthos yang berarti dari mulut ke mulut, atau dengan kata lain cerita informal suatu suku yang diteruskan dari satu generasi ke generasi berikutnya (Christensen, 2008). Biasanya mitos menceritakan mengenai terjadinya alam semesta, dunia, bentuk khas binatang, bentuk topografi, petualangan para dewa, dan sebagainya. Sedangkan legenda (legend) adalah cerita rakyat yang dianggap benar-benar terjadi dan biasanya mengenai manusia, kekuatan supranatural, tempat, atau objek. Legenda tidak terlalu dianggap suci seperti mitos.

Mitos dan legenda mengandung kebijaksanaan, pengalaman, dan nilai budaya. Metode pengajaran budaya lewat cerita yang mempunyai pesan moral sudah dilakukan sejak ribuan tahun lalu, cerita yang sama diteruskan dari generasi ke generasi dan mengalami distorsi dalam penyampaiannya sehingga tidak lagi dapat diketahui kebenarannya. Rodriguez (dikutip dalam Samovar, Porter, \& McDaniel, 2010:38) mengatakan beberapa tujuan dari mitos, legenda, dan dongeng dalam perkembangan budaya:

Dongeng tidak hanya dianggap sebagai pengawas terbaik bahasa dan warisan budaya, tetapi juga merupakan penolong hebat dalam proses sosialisasi, mereka mengajarkan anak-anak pelajaran yang kadang-kadang sulit tentang bagaimana berinteraksi dengan orang lain dan apa yang terjadi ketika kebaikan diadu dengan kejahatan.

Sedangkan Stephens dan Eisen mengatakan pentingnya mitos dalam kehidupan sehari-hari manusia (dikutip dalam Movva, 2004:42), yaitu:

Myth is the story that we tell to explain the nature of our reality. It is a whole picture constructed out of the particular pieces of our attitudes and beliefs. Myths become our touchstones to what is "real" and what is "important". They encompass the most basic, fundamental, and ultimate. They are the "truths" to which we look when trying to decide how we should conduct our lives, what we should actually do, and how we should think and feel.

Sehingga dapat disimpulkan tujuan dari mitos adalah sebagai perekat masyarakat yang dapat menjelaskan realitas dan budaya yang ada. Mitos memberikan panduan mengenai apa yang nyata dan penting bagi kehidupan suatu kelompok masyarakat. Terkait dengan mitos dan legenda, simbol dan metafora memainkan peran kunci dalam transformasi, baik ditingkat individu, group, organisasi, atau sosial. Hal ini dikarenakan simbol dan metafora mempunyai ketertarikan dari sisi nonrasional dan emosional manusia, dan mempunyai dampak mendalam pada kesadaran manusia (Movva, 2004). Di dunia literatur, mitos menjadi inspirasi untuk tulisan-tulisan fiksi dan tidak jarang juga mitos baru terbentuk sebagai perkembangan atau gabungan dari mitos-mitos lama. Sebagai contoh adalah Tolkien yang ingin menciptakan mitos Anglo Saxon dari kumpulan mitos Celtic dan berakhir dengan tulisan fiksi yang sangat terkenal (Fimi, 2006).

Dalam dunia modern, mitos juga memiliki fungsi dalam kehidupan sehari-hari dan dalam organisasi. Kepercayaan terhadap mitos membentuk pola pikir manusia dan bahkan nilai-nilai dalam organisasi. Penelitian dalam artikel ini memiliki tujuan sebagai berikut. Pertama, apa saja fungsi dari mitos-mitos yang memiliki tema paling terkenal dari kebudayaan di seluruh dunia; kedua, adakah hubungan antara mitos tersebut dengan budaya modern. Diharapkan dengan mendapatkan hasil penelitian dari masalah diatas didapatkan latar belakang mengenai budaya dan perilaku masyarakat modern, termasuk dalam kehidupan organisasi mereka. Adapun tujuan penelitian dari artikel ini adalah pertama, untuk mengetahui fungsi dari mitos-mitos dengan tema paling terkenal dari kebudayaankebudayaan di dunia. Lalu kedua, mengetahui latar belakang dan hubungan antara mitos dengan budaya masyarakat modern. 


\section{Landasan Teori}

\section{Fungsi Mitos}

Menurut Wilkinson \& Philip (2007:16) mitos mempunyai beberapa fungsi, yaitu: (1) jalan menuju kesucian: mitos menyediakan jalan menuju dunia para dewa yang suci dan bagaimana semua aspek dalam kehidupan manusia di dunia mempunyai akibatnya sendiri di dunia para dewa; (2) mengelola aktivitas manusia: dewa dan dewi dalam mitos membantu manusia dalam menjalankan aktivitas tertentu, misalnya dalam masyarakat Romawi kuno, seorang pria membutuhkan bantuan delapan dewa untuk melewati malam pertama dengan istrinya: Jugatinus, yang mempersatukan kedua manusia dalam pernikahan; Domidicus, yang mengantar sang istri pulang ke rumah barunya; Domitius, yang memasang posisi sang istri; Manturna, yang menahan posisi sang istri tersebut; Virginiensis, yang membuka pakaian sang istri; Subigus, yang membuat sang istri untuk menuruti keinginan suami; Prema, yang menahan sang istri; dan Pertunda, yang memungkinkan terjadinya penetrasi; (3) template/cetakan untuk kehidupan sehari-hari: mitos lebih dari sekadar cerita, mitos mempunyai fungsi untuk menjaga kehidupan dan interaksi manusia dalam bermasyarakat serta interaksi manusia dengan alam. Melalui struktur dan nilai yang dibawa dalam cerita tercipta sistem budaya, ritual, dan kepercayaan.

\section{Mitos Penciptaan}

Tema yang paling umum dari mitos penciptaan adalah adanya dewa pencipta, yang memisahkan langit dan bumi, serta menciptakan manusia baik dari tanah liat, ranting, keringat, bahkan kutu dari dewa pencipta itu sendiri (Wilkinson \& Philip, 2007, hal. 18). Dalam kebudayaan Mesir kuno, dewa pencipta ini adalah Amun-Ra, sedangkan dalam kebudayaan suku Indian Keres di Amerika, dewa pencipta mereka dikenal dengan nama Thinking Woman yang menciptakan alam semesta lewat pikirannya. Kepercayaan Kristen lewat mitos penciptaan selama enam hari juga termasuk dalam mitos penciptaan melalui kekuatan pikiran dewa.

Selain melalui kekuatan pikiran, ada beberapa kebudayaan yang memiliki mitos bahwa dunia diciptakan dari air yang tidak berujung, bahwa tanah akan muncul dari genangan air ini. Mitos penciptaan Babylonia menceritakan bahwa dunia dan isinya tercipta dari pertemuan antara air laut dan air tawar. Suku Ainu di Jepang juga percaya bahwa pada awalnya dewa pencipta Kotan-kor-kamuy mengutus berang-berang dari surga untuk menyelam ke dalam air dan mengambil tanah untuk membuat dunia.

Dalam kepercayaan Hindu, dewa Brahma adalah sumber dari segalanya dan penciptaan adalah proses berulang secara kontinu. Ketika Brahma bangun, dunia dan isinya akan tercipta, sedangkan ketika Brahma tidur maka seluruh dunia dan isinya akan hilang. Konsep penciptaan adalah proses berulang ini juga dipercayai oleh masyarakat Norwegia, bahwa perang akhir yang dikenal dengan nama Ragnarok akan menjadi suatu awal dunia yang baru.

Fungsi yang dapat diambil dari mitos penciptaan bahwa mitos ini memperkenalkan manusia pada kekuatan yang lebih besar yang "menciptakan" manusia. Mitos penciptaan ini juga memperkenalkan manusia pada dunia para dewa, yang harus dihormati dan mengajarkan manusia untuk tidak merusak hasil ciptaan lainnya. Kemiripan antarmitos dan fungsinya dapat dilihat secara detail di beberapa contoh berikut.

Menurut mitos penciptaan Yunani kuno (Page II, 2010), pada awal penciptaan hanya ada kehampaan yang bernama Chaos. Setelahnya muncul ada kekuatan bernama Gaia, mengambil bentuk burung merpati, dan menetaskan Uranus (dewa langit), Ourea (dewa gunung), Pontus (dewa laut), dan bagian-bagian lain dari cosmos. Gaia dan Uranus memiliki anak yaitu Cyclops, raksasa yang memiliki satu mata sebagai penghuni bumi pertama. Uranus tidak menyukai Cyclops karena dianggap dapat 
merebut kekuatannya, sehingga mengusir Cyclops untuk tinggal di dunia arwah (underworld). Setelahnya Gaia dan Uranus memiliki enam anak yang sangat kuat yang dikenal dengan Titans. Pemimpin dari Titans ini adalah Cronos dan seiring dengan waktu para Titans pun bertambah kekuatannya dan menjadi pemimpin di bumi. Anak-anak dari Titans ini dikenal dengan nama dewadewi Olympus, dan merekalah yang menciptakan manusia dengan bantuan Titan Prometheus, sebagai pelindungnya. Sedangkan berikut ini adalah mitos penciptaan Jepang (Danandjaja, 1997):

At the beginning of heaven and Earth, three invisible gods came into being; the Heavenly Centre Lord, the High Generative Force, and the Divine Generative Force. They were the first of the kami, or gods. From the primal ooze sprouted reed-shoots, which became two more of the gods: the god of Excellent Reed-Shoots and the god of Heavenly Standing. These first gods are the five Separate Heavenly Deities.

Izanagi and Izanami were the seventh generation of gods. They represent the yin and the yang, the male and the female principles, and they are the ancestors of all creation. Izanagi and Izanami descended the Rainbow Bridge, and created Onogoro, the first island. Observing the lovemaking of a pair of wagtails, Izanagi and Izanami felt desire for each other. They walked around a pillar, one from the right and one from the left, and when they met they had intercourse. This was their first wedding, but it was flawed, because Izanami spoke first. Their first child was Hiruko, the Leech-Child, whom they floated away on reeds. The gods advised them to repeat their wedding, but with Izanagi speaking first. They did this, and Izanami then gave birth to all the islands of Japan, and to the gods of the seas, rivers, winds, trees, mountains, and plains. Lastly she gave birth to the god of fire, Kagutsuchi, who burned her, making her vomit up and excrete yet more gods.

Mitos penciptaan Norwegia dan Islandia (Wilkinson \& Philip, 2007) adalah sebagai berikut:

The Norse creation story begins in the borderland between two cosmic regions, the frozen world of Niflheim and the hot realm of Muspell, a setting that recalls the icy terrain and bubbling geysers of Iceland, where the story has its origins. As the heat of Muspell began to thaw the ice of Niflheim, the evil giant Ymir emerged. Then a cow called Audhumla formed out of the melting ice, and produced milk for Ymir to drink. As he drank and was further warmed by the air of Muspell, Ymir started to sweat, and two more giants were formed in the sweat under his left arm while another emerged from his legs. When Audhumla licked the ice, she freed yet another giant, called Buri, from inside the ice. These frost giants ruled the cosmos. Buri's son Bor married Bestla, daughter of the giant Bolthorn, and had three children, the gods Odin, Vili, and Ve. Ymir was cruel to all around him, and the sons of Bor hated him. They fought the giant and killed him, and used his body as material from which to create the world. From his skull they made the sky; from his brain, the clouds. The gods made rocks from his bones and rivers and seas from his blood, which was so prolific that it drowned all the other frost giants except for two, Bergelmir and his wife. Odin, Vili, and Ve decided to explore the Earth. As they were walking along the coast, they found a pair of tree trunks washed up on the shore. The trio decided to bring life back to the dead trees, but in a new form. They remodelled the logs into humanoid shapes, and brought them to life. Odin gave the logs breath and life. Vili gave them intelligence and emotion. Ve gave them the senses of sight and hearing.

\section{Mitos Banjir Besar}

Seperti yang telah dibahas, dalam berbagai mitologi di seluruh dunia dikenal mitos penciptaan dari laut yang tidak berujung. Sehingga ketika dewa menciptakan banjir besar dinilai sebagai upaya untuk mengembalikan dunia menjadi suci kembali seperti sebelum penciptaan serta memungkinkan terjadinya awal yang baru. Dalam mitos masyarakat Chewong di Malaysia, dewa pencipta Tohan (Tuhan) akan mengirimkan banjir besar sewaktu-waktu yang akan menenggelamkan manusia kecuali mereka yang telah diperingatkan, dan Tohan akan menciptakan dunia baru setelahnya (Wilkinson \& Philip, 2007). 
Beberapa mitos banjir besar juga terpengaruh dari cerita dalam kitab suci mengenai Nabi Nuh dan bahteranya. Masyarakat Aborigin di Australia percaya bahtera Nabi Nuh terdampar di sana. Kepercayaan suku Inca bahwa dewa pencipta Viracocha merasa tidak puas dengan ras raksasa yang telah diciptakan. Sebelum menciptakan manusia, Viracocha mengirimkan banjir besar kepada ras raksasa ini, sehingga menenggelamkan mereka dan mengubah mereka menjadi batu. Masyarakat Inca percaya bukti dari kejadian ini adalah adanya patung-patung kuno di daerah Bolivia.

Konsep banjir besar sebagai hukuman juga kembali dikenal di kepercayaan Yunani kuno. Dewa Zeus mengirimkan banjir sebagai hukuman untuk kesombongan ras manusia yang pertama. Sebelum banjir terjadi, Prometheus sang Titan (raksasa) memberitahu anaknya Deucalion, sehingga anaknya dan istriya Pyrrha selamat dari banjir setelah membuat perahu dari peti-peti. Selain itu mitos banjir besar ini juga disebutkan dalam mitos mengenai Gilgamesh dari kota Uruk di Mesopotamia kuno. Dalam mitos tersebut diceritakan Gilgamesh yang ingin hidup abadi mencari petunjuk kepada Utnapishtim, satu-satunya manusia yang selamat dari banjir besar dan mempunyai hidup abadi. Utnapishtim bercerita bahwa para dewa marah dengan ulah manusia dan mengirimkan banjir besar untuk menghapus manusia, namun dewa air Ea datang ke Utnapishtim melalui mimpi dan memberitahukan padanya mengenai banjir yang akan terjadi dan menyuruhnya untuk membangun sebuah perahu. Kemiripan cerita ini dengan cerita Nabi Nuh sangat mengejutkan, terutama karena cerita Gilgamesh ini berasal dari tiga milenium sebelum masehi.

Salah satu mitos banjir sebagai hukuman yang paling terkenal adalah mitos mengenai pulau Atlantis, yang diciptakan oleh dewa Poseidon sebagai tanda cintanya kepada Cleito, Poseidon menginginkan Atlantis sebagai tempat yang makmur dan agar keturunannya dengan Cleito memerintah Atlantis dan daerah Mediterania dengan bijaksana. Namun seiring dengan waktu, keturunan mereka lebih mementingkan keinginan duniawi dan menjadi korup. Karena itu Poseidon yang diliputi amarah dan kesedihan mengirimkan gelombang tsunami yang menenggelamkan seluruh pulau Atlantis.

Mitos banjir besar ini berfungsi sebagai pengingat bahwa manusia penuh dengan kesalahan dan mudah tergoda. Jika tidak segera memperbaiki kesalahan ini, para dewa akan marah dan menghukum mereka. Mitos ini juga menjadi pengatur interaksi sesama manusia dan dengan lingkungannya, menjadi cetakan untuk kehidupan sehari-hari manusia. 2007):

Berikut adalah contoh mitos banjir besar dari masyarakat Slovenia (Wilkinson \& Philip,

The first humans enjoyed a life of paradisical ease in a valley where everything grew without the need for toil. The valley was irrigated by seven rivers that flowed from an egg, and was surrounded by high mountains. The people became very lazy and complacent: they could not even be bothered to pick up the bread that grew on the trees, but instead set fire to the trees so that the bread fell into their hands. The people decided to break the egg and each take as much water as they wanted. The egg split with a roar like thunder and water poured from it, filling the valley, until there was nothing but an enormous lake. All the people died except Kranyatz, the watchmen on guard on the highest mountain top. Kurent (a trickster god) stretched down and held out his walking stick - a vine to save Kranyatz, who clung to its tendrils for nine years until the flood waters receded, nourishing himself in the meantime on the vine's grapes.

Sedangkan di bawah ini adalah contoh mitos dari Cina (Wilkinson \& Philip, 2007):

Long ago, the Emperor of Heaven grew angry with humanity because of its sinful ways, so he sent a terrible flood as punishment. The rivers burst their banks, houses were destroyed, and many people were drowned. Gun, the grandson of the Emperor of Heaven, took pity on the people and went down to Earth to mend the river banks. He took with him soil from heaven to absorb the water. But he did not tell his grandfather what he was doing, and when the Emperor of Heaven found out, he was angry again and had Gun killed. Gun's body did not decay like a 
human body. Instead a new life form, the dragon Yu, grew inside his corpse and emerged from Gun's body. When Yu saw the flood damage he flew off to heaven to plead with the emperor to have mercy on humanity. The emperor relented and allowed Yu to repair the damage. Yu worked hard, raising new hills and mountains, mending the river banks, and building new channels to take away the water. After 30 years the floods were banished and the planet was safe once again.

\section{Mitos Kematian}

Manusia selalu berusaha mencari kepastian, termasuk dalam kematian. Mengapa manusia harus meninggal? Apa yang terjadi setelah seseorang meninggal? Mitos-mitos mengenai kematian berusaha menjawab kedua pertanyaan ini dan memberikan suatu kepastian sementara untuk dipercayai oleh manusia. Jawaban dari kehidupan setelah kematian ini juga dikenal telah mengubah sejarah. Pada 627, raja Inggris, Edwin dari Northumberia, mengadakan pertemuan dengan para penasihatnya mengenai apakah dia harus pindah ke agama Kristen atau tidak. Salah satu penasihatnya memberikan masukan bahwa tidak ada yang tahu apa yang akan terjadi setelah kematian, paganisme tidak memberikan jawaban mengenai hal itu dan agama Kristen menawarkan jawaban mengenai hal tersebut. Berdasarkan jawaban ini, maka Edwin setuju untuk pindah dari Paganisme menjadi Kristen, begitu pula dengan Coifi, pendeta tinggi paganisme yang menyuruh untuk menghancurkan kuil-kuil paganisme (Wilkinson \& Philip, 2007).

Mitos yang dikenal oleh bangsa Mesir mengatakan akan adanya hari penghakiman dan bahwa dunia setelah kematian terdiri dari jalan sempit yang dilalui sungai dan gunung yang memisahkannya dari dunia manusia. Suku Guarayu di Bolivia juga mempunyai mitos bahwa setelah meninggal, seseorang akan diberikan pilihan berupa dua jalan, yang satu lebar dan mudah sedangkan yang satunya sempit dan sulit dilalui. Jika memilih jalan yang sempit, orang tersebut akan mengalami berbagai cobaan sebelum bergabung dengan dewa pencipta Tamoi di surga.

Pada masyarakat kebudayaan kuno, manusia juga sudah menginginkan untuk hidup abadi, memiliki kemudaan yang abadi seperti para dewa dan dewi mereka. Mitos Yunani mengenai Sibyl dari Cumae memberikan jawaban atas keinginan manusia ini: Dewa Apollo yang jatuh cinta pada Sibyl menawarkan untuk mengabulkan apa pun permintaanya. Saat itu Sibyl meminta untuk diberikan umur sebanyak butiran pasir yang dapat digenggamnya. Apollo mengabulkan permintaannya, namun Sibyl, dengan kecantikan abadi, menolak cinta Apollo yang menyebabkan Apollo membuatnya menjadi sangat tua dan lemah namun tetap tidak dapat mati.

Kepercayaan bangsa Mesir mengenai hidup setelah kematian maupun proses mumifikasi yang mereka lakukan adalah untuk meyakinkan seseorang yang meninggal dapat tinggal di Field of Reeds, tempat peristirahatan terakhir, dengan tubuh yang sempurna. Bangsa Mesir percaya untuk mencapai hidup baru ini, maka semua elemen dari seseorang yang telah meninggal harus dirawat dan tidak boleh rusak, termasuk badan/raga, nama, dan bayangan orang tersebut. Karena itulah raga seseorang harus melalui proses mumifikasi agar tidak membusuk dan dapat bersatu kembali dengan jiwanya di alam sana. Setelah seseorang meninggal, jiwa orang itu dipercaya akan mengalami perjalanan dan negosiasi dengan dewa Anubis. Hati orang tersebut akan ditimbang dengan Feather of Truth (bulu kebenaran). Jika hati orang ini diberati oleh dosa, hatinya akan lebih berat dari bulu kebenaran tersebut, dan jiwa orang tersebut akan dimakan oleh Ammut. Namun jika hati orang ini tidak lebih berat, Horus akan menunjukkan jalan menuju rumah Osiris, tempat peristirahatan terakhir.

Mitos mengenai kematian ini mengajarkan pada manusia untuk menerima bahwa semua makhluk pada akhirnya akan meninggalkan dunia. Beberapa mitos berusaha menawarkan jawaban yang ada pada alam setelah kematian: siksaan bagi mereka yang menjalani hidup dengan buruk dan kenikmatan surgawi bagi mereka yang menjalani hidup dengan baik. Dasar mengenai adanya kehidupan setelah kematian ini yang membuat template, kebiasaan dan ritual di kehidupan sehari-hari 
manusia, dengan harapan manusia menjalani hidupnya dengan baik untuk mendapatkan kenikmatan surgawi setelah mereka meninggal.

Berikut ini adalah contoh mitos kematian suku Maori di New Zealand (Wilkinson \& Philip, 2007):

Tane, god of the forest, was lonely, and wanted a sexual partner. His mother rejected him, and his other partners produced only inadequate things such as streams, grass, and stones. So finally he went to the beach at Hawaiki, mixed together some mud and sand, and shaped it into a woman. He breathed life into her, and called her Hine-hau-one, the Earth-formed Maiden. Hine-hau-one gave birth to a daughter, Hine-titama, the Dawn Maiden. Not knowing that Tane was her father, Hine-titama also became his wife. One day Hine-titama went down to the village and idly asked who her father was. When she heard the answer, she fled to the darkness of the Underworld. When Tane realized Hine-titama had disappeared, he went looking for her. He could hear her singing a sad song, "Are you Tane, my father?" and called to her, but he could not enter Po, the Underworld. She called to him, saying: "Stay in the world of light, and foster our offspring. Let me stay in the world of darkness, and drag our offspring down." Her name was changed from the Dawn Maiden to Hine-nui-te-po, the Great Goddess of Darkness. Before this happened, death did not exist, but now all living things must die, sucked down to the Underworld by Hine-nui-te-po.

\section{Mitos Akhir Dunia}

Sama seperti mitos yang menjelaskan mengenai penciptaan dunia, maka mitos juga menjelaskan mengenai bagaimana dunia akan berakhir dan apa yang dapat dilakukan oleh manusia untuk mencegah hal tersebut. Hampir di setiap mitos yang menceritakan mengenai akhir dunia juga disertai dengan bencana yang telah terjadi di masa lalu dan peringatan bagi masyarakatnya mengenai bencana lebih besar di masa depan.

Suku Indian Maya percaya bahwa waktu adalah sarana yang memerangkap dewa-dewa perusak di dalam bintang-bintang di angkasa. Hal ini juga dipercaya oleh masyarakat Persia melalui mitos Zoroastrian-waktu adalah sarana yang menjaga dewa perusak Ahriman agar tidak merusak dunia. Sedangkan bangsa Mesir percaya suatu waktu nanti dewa Ra akan merasa lelah dengan dunia yang ada sekarang ini, dan karena itu akan mengakhiri dunia yang dia ciptakan.

Dari mitos-mitos seperti ini muncul ritual-ritual untuk mencegah akhir dari dunia yang harus dilakukan oleh manusia secara berkala. Seperti perayaan tahun baru bangsa Babylonia kuno ditujukan untuk menjaga kekuatan jahat di luar dunia dan memberikan kesempatan bagi dewa Marduk untuk menjaga keseimbangan dunia selama setahun berikutnya (Wilkinson \& Philip, 2007).

Nilai-nilai implisit dari ritual seperti ini berasal dari ide bahwa manusia harus melakukan sesuatu agar dunia tidak berakhir atau berubah kembali ke fase awal (lautan tidak berujung). Manusia harus menjaga dunia dan lingkungan alam agar tidak terjadi bencana lebih besar.

Berikut mitos akhir dunia yang dipercayai oleh penganut agama Zoroastria di Persia (Wilkinson \& Philip, 2007):

Ahura Mazda, the wise and all-knowing, made the sun, the moon, and the stars, and the Good Mind that works within man and all creation. Ahriman attacked him with demons, but Ahura Mazda banished him to the darkness. Then Ahura Mazda created the first man, Gayomart, and the world would have been perfect, but the malicious Ahriman broke through the sky in a blaze of fire, bringing with him starvation, disease, pain, lust, and death. He defiled everything he touched and rejoiced as he did so. "My victory is perfect," he crowed. "I have fouled the world with filth and darkness, and made it my stronghold. I have dried up the Earth, so that the plants will die, and poisoned Gayomart, so he will die." Gayomart did indeed die, but Ahura Mazda created the mother and father of humanity - Mashya and Mashyoi - from Gayomart's 
seed. All humans are descended from them, and are born good, but Ahura Mazda leaves them free to choose between good and evil. Ahura Mazda can not defeat Ahriman, so he set a limit to time, and trapped Ahriman inside creation. Ahriman was unable to escape, and will remain in the world doing evil until the end of time. Ahura Mazda does his best to counter this with the help of seven gods including Mithra, the sun god. As the end time draws near, the savior Saoshyant will arise. He will prepare the world to be made anew. And help Ahura Mazda destroy Ahriman. People will become pure: they will stop eating and drinking, until at last they survive on air. Ahura Mazda will cast Ahriman from creation, time will come to an end, and the world will begin again, but this time it will be perfect. Saoshyant will raise the dead, and Ahura Mazda will marry body to soul.

\section{METODE}

Metode penelitian yang dipakai di penelitian ini adalah library research melalui studi dari kepustakaan, dokumentasi, dan penelitian terdahulu. Analisis data dilakukan dengan metode framing. Menurut Eriyanto (2002:11), analisis framing termasuk paradigma konstruksionis yang diperkenalkan Peter L. Beger. Pendekatan Konstruksionis mempunyai penilaian tersendiri mengenai wartawan, media, dan berita. Fakta atau sebuah peristiwa adalah hasil konstruksi yang bersifat subjektif yang dilakukan oleh wartawan dengan sudut pandang tertentu. Analisis framing merupakan suatu metode yang digunakan untuk menganalisis media. Analisis framing secara sederhana digambarkan sebagai suatu analisis untuk mengetahui realitas (peristiwa, aktor, kelompok, dan apa saja) dibingkai media. Pembingkaian tersebut melalui sebuah proses konstruksi. Realitas sosial dimaknai dan dikonstruksi dengan makna tertentu dan peristiwa dipahami dengan bentukan tertentu. (Eriyanto, 2002: 3)

Framing adalah suatu proses membuat suatu pesan lebih menonjol, menempatkan informasi lebih daripada yang lain sehingga khalayak lebih tertuju pada pesan tersebut. Menurut Pan Kosicki dalam Eriyanto (2002:252) ada dua konsepsi framing yang saling berkaitan. Pertama, konsepsi psikologi melihat pada proses internal seseorang dan menekankan bagaimana seseorang memproses informasi dalam dirinya. Framing berkaitan dengan struktur dan proses koginitif, bagaimana seseorang mengolah sejumlah informasi dan ditunjukkan dalam skema tertentu. Framing dilihat sebagai penempatan informasi dalam suatu konteks yang unik atau khusus dan menempatkan elemen tertentu dari suatu isu dengan penempatan lebih menonjol dalam kognisi seseorang. Elemen yang diseleksi dari suatu isu/peristiwa tersebut menjadi lebih penting dalam memengaruhi pertimbangan. Elemen yang diseleksi dari suatu isu/peristiwa tersebut menjadi lebih penting dalam memengaruhi pertimbangan. Kedua, konsepsi sosiologis melihat konstruksi sosial atas realitas. Frame dipahami sebagai proses bagaimana orang mengklasifikasi, mengorganisasikan, dan menafsirkan pengalaman sosial untuk mengerti dirinya dan realitas di luar dirinya. Frame berfungsi membuat suatu realitas menjadi terindentifikasi, dipahami dan dapat dimengerti karena sudah dilabel dengan label tertentu.

Sebagai verifikasi, maka dilakukan wawancara kepada dosen Komunikasi Antarbudaya, ibu YS, mengenai masalah dalam penelitian ini. Wawancara dilakukan pada Januari 2015. Ibu YS dipilih karena dianggap ahli dalam konteks budaya sehingga pendapatnya dapat dikategorikan sebagai pendapat ahli. 


\section{PEMBAHASAN}

Seperti apapun bentuk dan cerita yang terkandung dalam mitos, cerita-cerita ini adalah elemen dasar dari setiap agama yang ada di dunia. Mitos menceritakan mengenai kepercayaan terhadap kekuatan yang lebih besar dari manusia, dari mana manusia berasal, dan bagaimana interaksi yang seharusnya dilakukan oleh manusia dengan kekuatan yang lebih besar ini. Walaupun terkesan fiksi, tidak dapat dipungkiri bahwa mitos menceritakan kebenaran mengenai manusia.

Mitos juga bersifat ambigu dan mempunyai banyak arti. Tidak ada mitos yang permanen, melainkan hampir semua mitos bersifat fleksibel, cerita di dalam mitos kebanyakan beradaptasi dengan pengetahuan baru dan perubahan dalam lingkungan manusia. Jika cerita dalam mitos tidak beradaptasi, arti yang dibawa akan mengalami pergeseran sesuai dengan kemajuan pemikiran para pengikutnya (Ryan, 2010).

Beberapa tema universal dalam mitos hampir selalu terdapat di berbagai kebudayaan di dunia, tema, dan nilai-nilai yang dibawa dalam mitos ini akan berkembang menjadi aturan-aturan dan kebiasaan-kebiasaan yang harus dilakukan manusia untuk menghormati alam dan para dewa, aturan dan kebiasaan ini berujung pada budaya yang diwariskan turun temurun dan mengalami distorsi dalam penyampaian ke generasi berikutnya. Jika diperhatikan dari beberapa contoh, tema yang diambil dalam mitos selalu disesuaikan dengan lingkungan tempat tinggal masyarakat tersebut. Misalnya, masyarakat yang tinggal di pegunungan atau hutan akan mempunyai banyak mitos yang terkait dengan sungai dan tidak ada satupun mitos yang terkait dengan lautan. Begitu pula sebaliknya, hal ini menjadikan mitos tersebut terkesan nyata dan makin dipercaya.

Berdasarkan wawancara yang dilakukan kepada ibu YS, sebagai dosen Komunikasi antarbudaya di beberapa kampus swasta di Jakarta, dinyatakan bahwa mitos sangat erat kaitannya dengan agama. Terutama, untuk orang Indonesia memiliki karakteristik sangat percaya kepada mitos, dan tanpa sadar dibungkus dengan hal-hal agamis. Sebagian masyarakat lainnya yang tidak percaya mitos memilih untuk percaya kepada ilmu pengetahuan. Perbedaannya jika ditanya, misalnya, mengenai penciptaan dunia, orang yang percaya pada agama akan menjawab dunia diciptakan oleh Tuhan YME, sedangkan yang percaya pada science akan menjawab karena adanya ledakan besar antarbintang (teori Big Bang). Namun di balik agama maupun ilmu pengetahuan tetap ada unsur mitos yang mendasari, sehingga mitos tetap berperan penting pada perilaku manusia modern.

Nilai yang dibawa oleh mitos juga mengandung kebenaran. Walaupun manusia sudah hidup di zaman modern, mitos masih memegang peranan penting dalam kehidupan manusia. Mitos memberikan manusia sesuatu untuk dipercayai dan ditakuti; mitos juga membawa harapan bagi manusia. Jika tidak ada mitos, tidak ada nilai untuk mengatur aktivitas kehidupan manusia. Percaya atau tidak, kita tidak ingin adanya bencana banjir besar yang diturunkan untuk ke sekian kalinya.

Masih menurut ibu YS, mitos penciptaan berfungsi sebagai pedoman atau guidance agar manusia mengetahui dari mana mereka berasal dan menjadikan dunia ini lebih mudah untuk dimaknai. Sedangkan mitos banjir besar tetap dipercaya sebagai hukuman dari Tuhan YME karena manusia yang telah banyak berbuat dosa. Contohnya di Indonesia ketika terjadi bencana alam tsunami yang menimpa Aceh tahun 2004 lalu. Tidak sedikit masyarakat yang percaya tsunami terjadi untuk menghukum masyarakat Aceh karena berbagai dosa atau untuk menghukum pemimpin atas dosa bangsa Indonesia. Mitos dengan tema kematian dan akhir dunia memiliki fungsi yang berbeda, yaitu sebagai panduan tujuan atas hidup manusia. Agar hidup manusia di dunia tidak sia-sia dan lebih bermakna, mitos yang menawarkan tujuan hidup setelah kematian dipercaya untuk memberikan rasa nyaman. Sekarang ini mitos tidak lagi diturunkan secara lisan, melainkan menggunakan banyak media seperti film, buku, maupun dalam bentuk dongeng. Fungsi lain dari mitos adalah sebagai pedoman 
etika mana yang baik dan mana yang buruk dari perilaku manusia dan sebagai pedoman etika di masyarakat.

Di zaman modern, nilai-nilai dalam mitos tetap dipelihara dan diturunkan melalui media modern, salah satunya adalah melalui film layar lebar. Sebagai contoh, film produksi Hollywood selalu mengedepankan mitos bahwa Amerika adalah bangsa terhebat. Jagoan dalam cerita biasanya adalah orang Amerika, sedangkan film produksi Inggris memiliki fantasi untuk menantang pasar Amerika dan film buatan Hollywood (Swann, 2000). Nilai-nilai utama mitos ditambah dengan persepsi modern inilah yang akan diturunkan ke masyarakat, sehingga masyarakat memiliki persepsi baru dan berujung pembuatan cerita mitos baru. Contoh dari hal ini adalah Disney yang mengubah cerita film klasik mereka, pada cerita klasik digambarkan wanita hanya bisa menunggu diselamatkan oleh pria namun di versi modern diganti dengan nilai-nilai keluarga. Pergeseran ini menandakan fungsi modern dari mitos.

Hal ini sejalan dengan fungsi mitos menurut Wilkinson dan Philip (2007:16) bahwa mitos mengatur aktivitas sehari-hari manusia baik disadari maupun tidak, dan mitos juga mejadi cetakan atau template mengenai apa yang baik dan buruk di suatu masyarakat. Walaupun mitos selalu berkembang, nilai-nilai inti yang disampaikan selalu sama dan berupa pedoman agar manusia dapat survive di lokasi atau situasi tertentu.

\section{SIMPULAN}

Fungsi dari mitos penciptaan adalah untuk memberikan latar belakang dari mana manusia berasal agar dunia dapat lebih mudah dimaknai. Kecenderungan manusia agar memaknai hal-hal di sekelilingnya menjadi pedoman untuk berperilaku dan mengatasi situasi di sekitar mereka. Fungsi dari mitos banjir besar adalah sebagai pengingat akan hukuman jika manusia terlalu berdosa. Dengan kata lain sebagai pedoman agar manusia tidak berbuat hal-hal negatif melainkan terus berperilaku baik sesuai dengan aturan etika di masyarakat. Sedangkan untuk tema mitos ketiga, mengenai kematian memiliki fungsi yang sama dengan mitos akhir dunia, yaitu sebagai pedoman tujuan kepada manusia agar hidup mereka tidak sia-sia. Dengan adanya tujuan akhir, maka manusia akan mencoba menyusun perilaku sehari-hari untuk mengarah ke tujuan akhir tersebut. Dapat disimpulkan dari keempat tema besar mitos yang banyak muncul di berbagai kebudayaan di dunia, fungsinya sebagai template atau cetakan atas apa yang baik dan apa yang buruk dalam kehidupan masyarakat, fungsi lain adalah sebagai dasar yang mengatur aktivitas sehari-hari manusia. Hal ini sejalan dengan fungsi mitos menurut Wilkinson dan Philip (2007).

Untuk masalah penelitian kedua, mengenai hubungan antara mitos dengan kehidupan masyarakat modern, mitos menjadi dasar kepercayaan masyarakat saat ini, baik berbentuk agama, kepercayaan, maupun ilmu pengetahuan. Hal-hal ini mengatur persepsi masyarakat dan berujung pada perilaku masyarakat sehari-hari. Dengan mengetahui hal-hal yang baik dan buruk tanpa sadar membentuk manusia untuk berperilaku sesuai hal-hal yang baik.

Sebagai saran, mitos tetap diperlukan oleh manusia bahkan sampai saat ini. Karena itu perlu adanya keberlangsungan penyampaian mitos kepada generasi penerus. Saat ini mitos dapat disampaikan baik dalam bentuk lisan, melalui dongeng kepada anak, maupun dalam bentuk nonlisan hingga bentuk digital, misalnya dalam bentuk film dan buku. Karena adanya pergeseran nilai-nilai dari tradisional menjadi modern, mitos juga akan bergeser. Maka dari itu, tetap diperlukan sosialisasi dan penyesuaian mitos dalam kehidupan manusia. Dengan menyadari mitos memberikan panduan bagaimana manusia harus bersikap akan membantu untuk memahami perilaku diri sendiri sehari-hari. Meskipun begitu, terlalu percaya pada mitos juga akan membawa hal negatif, sehingga diperlukan keseimbangan dalam berpikir antara mitos dan kehidupan nyata. 


\section{DAFTAR PUSTAKA}

Christensen, P. (2008). The "Wild West": The life and death of a myth. Southwest Review, 310.

Danandjaja, J. (1997). Folklor Jepang Dilihat dari Kacamata Indonesia. Jakarta: Pustaka Utama Grafiti.

Eriyanto. (2002). Analisis Framing. Yogyakarta: LKiS Yogyakarta.

Fimi, D. (2006). "Mad" Elves and "Elusive Beauty": Some Celtic Strands of Tolkien's Mythology. Folklore , 117(2), 156-170.

Movva, R. (2004). Myths as a vehicle for transforming organizations. Leadership \& Organization Development Journal , 25(1), 41-57.

Page II, L. W. (2010). Finishing Mysteries of Gods and Symbols. Egypt.

Ryan, M. (2010). Cultural Studies: A Practical Introduction. Singapore: Blackwell.

Samovar, L. A., Porter, R. E., \& McDaniel, E. R. (2010). Komunikasi Lintas Budaya. Jakarta: Salemba Humanika.

Swann, P. (2000). The British Culture Industries and the Mythology of the American Market: Cultural Policy and Cultural Exports in the 1940s and 1990s. Cinema Journal , 27-43.

Wilkinson, P., \& Philip, N. (2007). Mythology. London: Dorling Kindersley. 